\title{
The Relationship Between Information Transparency And The Informativeness Of Accounting Earnings
}

Lin, Yu-Chih, National Yunlin University of Science and Technology, Taiwan

Huang, Shaio Yan, (E-mail: huangsy@fcu.edu.tw), Feng Chia University, Taiwan

Chang, Ya-Fen, Providence University, Taiwan

Tseng, Chien-Hao, Feng Chia University, Taiwan

\begin{abstract}
The issue of corporate governance has prompted calls for greater transparency and disclosure on companies around the world. As a result, a disclosure ranking system, Information Transparency and Disclosure Ranking System (ITDRS) was launched in Taiwan since 2003 by the request of Taiwan Stock Exchange Corporation (TSEC). This paper examines the relationship between information transparency and the informativeness of accounting earnings. The empirical tests are conducted using TEJ database for firms listed on the Taiwan Stock Exchange with fiscal year ends between 2003 and 2004. Empirical results indicate that, information transparency, measured by the ranking of ITDRS, reduces the informativeness of accounting earnings. However, if information transparency is measured by the ratio of long-term investment in stocks, evidences show higher earnings response coefficients (ERC) for the more transparent firms. The results suggest that accounting numbers are more useful or valuable than the ITDRS ranking results from investors' perspective. It also suggests that the ITDRS may be not a good proxy for financial transparency.
\end{abstract}

\section{INTRODUCTION}

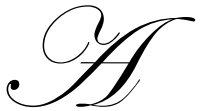

fter the Asian financial crisis, information transparency and quality of disclosure of companies have caused much concern among members of the business community. According to the World Bank and Asian Wall Street Journal, publicly listed companies in South Asian countries are still grappling with the problem of low information transparency (World Bank, 1999; Asian Wall Street Journal, 1999). Taiwan is not an exception; from the latter half of 1998, the country has seen a lot of financial crises unfold; financial transparency of publicly listed companies has become a focus of concern among investors. Aside from being concerned about the converge of local accounting standards with international accounting standards, the securities market watchdog also made efforts to improve other disclosure environments. For example, Securities and Futures Institute (hereafter SFI), entrusted by the Taiwan Stock Exchange Corporation (hereafter TSEC) has launched Information Transparency and Disclosure Ranking System (hereafter ITDRS) to evaluate the level of transparency for all listed companies in Taiwan since 2003.

In this paper we examine the association between the level of information transparency and the informativeness of accounting earnings. We measure information transparency using both ITDRS ranking results and the ratio of long-term investment in stocks. Empirical results indicate that, information transparency, measured by the ranking of ITDRS, reduces the informativeness of accounting earnings. However, if information transparency is measured by the ratio of long-term investment in stocks, evidences show higher earnings response coefficients (ERC) for the more transparent firms. The results suggest that accounting numbers are more useful or valuable than the ITDRS ranking results from investors' perspective. It also suggests that the ITDRS may be not a good proxy for financial transparency.

In order to access the transparency and disclosure practices of listed companies, ITDRS identified 88 disclosure items as evaluation criteria grouped into the following five categories: 
- $\quad$ Compliance with the mandatory disclosures

- $\quad$ Timeliness of reporting

- $\quad$ Disclosure of financial forecast

- $\quad$ Disclosure of annual reports

- $\quad$ Corporate website disclosure

A two-stage of screening process was conducted by SFI. All information provided by companies was preliminarily screened by the SFI in-house ranking team based on the existence of each disclosure item. All companies were entitled to check the preliminary result via internet, then directly respond to the SFI regarding ambiguous issues in two weeks. Upon receiving the different opinions expressed by companies, the Ranking Committee, composed of experts from accounting profession, industry and academia, subsequently accessed the presentation and decided the final list of the more transparent companies.

The level of transparency is difficult to measure. The 88 disclosure items of ITDRS are comprehensive, but may be not a good proxy of corporate transparency. From investors' points of view, the least transparent item in financial statement is long-term investment in stocks due to the complicated pyramidal and cross-holding ownership structures. Since many corporate financial failures are related to insufficient disclosure of long-term stock investment, Chang (1999; 2002); Hsue (2002) and Yeh (2004) have pointed out that the ratio of long-term stock investment is one of the major concerns for investors.

The higher the amount of long-term investment, the lower the financial transparency, listed companies are trying to reduce the ratio of long-term stock investment to convince investors that they are financially transparent. For example, in 2000, the UMC group merged its subsidiaries, Lien Cheng, Lien Rei, Lien Chia, and Hotai, companies into the parent company. Long-term investment in stocks, which was considered by the outside world as having low transparency, was reduced. The result not only raised the level of transparency of financial information, it also enhanced the company's business performance. In another case, the Acer group carried out a series of reorganization in 2002. One of the goals was to change the originally complex investment structure to raise the level of business efficiency and make it more transparent to investors. Thus, it is worthwhile to examine the association between information transparency and the informativeness of accounting earnings using the ratio of long-term stock investment as proxy of information transparency. The rest of the paper is organized as follows. Section 2 is the review of related literature. Section 3 discusses the methodology of the research, including research hypothesis, empirical model, sample and variables. Section 4 discusses our empirical evidence. We conclude this paper in Section 5.

\section{LITERATURE REVIEW AND HYPOTHESIS DEVELOPMENT}

\section{Information Transparency}

If management owns "private" information, it will result in information asymmetry which in turn breeds moral hazards and adverse selection (Barnea et al. 1985). Healy and Palepu (2001) pointed out that, through financial report and information disclosure, companies can lower information asymmetry and agency conflicts between management and external investors. It is well recognized that the quality of corporate disclosure influences to a great extent the quality of investment decisions. Elliott and Jacobson (1994) analyze the costs and benefits of corporate disclosures. The potential benefits of more disclosures include lower cost of capital (Botosan 1997; Diamond and Verrecchia 1991), agency cost reduction (Leftwich et al. 1981) and improved share price (Gelb and Zarowin 2002; Lang and Lundholm 2000). When the information disclosure of an economic entity is adequate; it helps the investors and creditors in their search for investment opportunities, to pour capital into the most productive of companies. This in turn promotes optimum allocation of resources; consequently, aside from enhancing corporate value, information disclosure benefits also improves the development of the economy as a whole.

Lang and Lundholm (2000) examined disclosure activity around equity offerings and its relationship to stock prices. They found that firms that maintain a consistent level of disclosure experience price increases prior to the offering. Ho and Wong (2001) also pointed out that increasing the disclosure within the annual report may reduce information asymmetry, improve management performance, save costs in terms of the investor's privately produced information, and enhance corporate image. It satisfies the needs of the information users and achieves the goal of lowering the company's investment costs. 


\section{The Measurement of Information Transparency}

How to assess and quantify transparency are very real and current difficulties. Gelb and Zarowin (2002) examined the association between voluntary corporate disclosure and the informativeness of stock price using the AIMR-FAF ( Association for Investment Management Research-Financial Analysts Federation, hereafter AIMR ) annual corporate disclosure ratings. They found that greater disclosure is associated with stock prices that are more informative about future earnings (i.e., higher future ERC). In addition, Bens and Monahan (2004) also used the AIMR review results as the information disclosure level indicator to study the relationship between the level of information disclosure and diversity. Results show that there is a positive relationship between the disclosure quality assessed by AIMR and the excess value of diversification.

Botosan (1997) studied the relationship of voluntary disclosure and ownership capital costs, using the market's $\beta$ value to estimate the ownership capital costs. The disclosure standards are assessed through the voluntarily disclosed items in the annual report provided. The study used content analytical method disclosure indicators, which are categorized into five major categories; a total of 35 disclosure items were used to assess the company's annual report voluntary disclosure standards. Results indicate that: (1) in companies that attract less attention from analysts, there is a negative relationship between standards of disclosure and capital costs; (2) in companies that attract more attention from analysts, the relationship between voluntary disclosure and capital is not important.

Cooke (1991) used annual reports from Japan to assess the level of voluntary disclosure and explore the effects of annual report voluntary disclosure standards. There were 106 voluntary disclosure items in the study; a corresponding standard was used to assess the level of voluntary disclosure of the company; the company's actual scores were divided by the scores it should get. Results show that: (1) in Japan, company size is the major deciding factor of voluntary disclosure; (2) publicly listed companies and manufacturing concerns voluntarily disclose more information.

Meek (1995) studied the factors affecting the voluntary disclosure level in the annual reports in the US, England, and European countries. The study results show that: (1) strategic information disclosure is affected by regional differences and international position. Compared to the US and Great Britain, multinationals operating in Europe or are publicly listed in other countries voluntarily disclose more information; (2) disclosure of non-financial information is affected by regional differences company sizes and industry category; and (3) level of financial information disclosure is affected by company size, regional differences, and industry category. In addition, companies which are publicly listed in other countries volunteer more information than companies which operate only within a single country.

Ho and Wong (2001) studied the relationship between the company's administrative structure and the scope of voluntary disclosure, with a focus on publicly listed Hong Kong companies. In the study, company administrative attributes included ratio of independent board members in the total number of people in the board of directors, the existence of audit committees, whether the CEO and Chairman are the same person, ratio of family members in the board of directors, and the stock ratio of a single family. The study's voluntary disclosure is assessed by using the relative disclosure index (RDI). The study was conducted through survey; it focused on 535 financial analysts and screened the voluntary disclosure status of 20 assessed sample companies. Results show that the existence of the review commission and voluntary disclosure level has a positive relationship, while the ratio of family members in the board and voluntary disclosure level has a negative relationship.

Yeh (2002) used the website information disclosure of Taiwan's publicly listed companies to assess transparency, surveying the current status of 555 companies listed on the Taiwan Stock Exchange in terms of amount of company information presented on the company website. Results indicate that of the 555 companies, $89 \%$ have official websites; only $33 \%$ feature financial information. From this, it is evident that the websites of many companies usually introduce the company and its products; they disregard the information needed by investors. Consequently, it is necessary for local public companies to improve this aspect.

Chen et al. (2005) examined factors influencing firm's internet disclosures in terms of three dimensions: corporate characteristics, inside and outside ownership. They found companies with high degree of leverage, large number of employee and operating in the IT sector tend to disclose more information. 
Chang and Fang (2006) studied whether the implementation of the information disclosure review system was able to effectively lower corporate earning management behavior. They also studied whether the results of the information disclosure review system were able to effectively categorize the discrepancy of the level of corporate earnings management. Results indicate that after the implementation of the review system, corporate earnings management behavior evidently went down; companies whose management had more stocks on their hands were more evidently affected by the system. However, there was no evident relationship between the level of transparency and level of earnings management. The results may be caused by the information disclosure review system and not by the effective assessment indicators of transparency.

\section{Informativeness Of Earnings}

The earnings informativeness is well documented (e.g. Beaver, Clarke and Wright 1979; Brown and Warner 1980; Brown and Warner 1985; Collins et al 1987; Strong and Walker 1993 and others). Fan and Wong (2002) examine the relationship between corporate ownership structure and the informativeness of accounting earnings in East Asia. We follow the research of Fan and Wong (2002) and use earnings-return relation to measure earnings informativeness of Taiwan's TSEC- and OTC-listed companies. Based on the above discussion, we hypothesized a positive relationship between informativeness of accounting earnings and information transparency; i.e., the more transparent firms have greater price informativeness.

\section{RESEARCH DESIGN AND SAMPLE}

\section{Empirical Model}

This study uses the earnings-return model to examine the informativeness of accounting earnings. Company earnings are measured by net income; abnormal returns are measured by net-of-market returns. The abnormal returns of i company on $t$ year are calculated as such:

$$
A R_{i t}=R_{i t}-R_{m t}
$$

$A R_{i t}$ is the average abnormal return rate of the i company stock on $\mathrm{t}$ year; $R_{i t}$ is the actual rate of return of the i company stock on t year; $R_{m t}$ is the market return rate on t year.

To explore the effects of level of information transparency and informativeness of accounting earnings, we first assess the informativeness of accounting earnings using the following regression model:

$$
A R_{i t}=a_{0}+a_{1} \Delta N I_{i t}+\mu_{i t}
$$

where $A R_{i t}$ is the average abnormal return rate of the i company stock on t year; $\Delta N I_{i t}$ is the net income variable of the i company stock on the $t$ year and $a_{1}$ is the earnings response coefficient (ERC); $\mu_{i t}$ is the error term. follows:

The model used to examine the relationship between transparency and earnings informativeness is as

$$
A R_{i t}=a_{0}+a_{1} \Delta N I_{i t}+a_{2} \Delta N I_{i t} T R A_{i t}+a_{3} \Delta N I_{i t} S I Z E_{i t}+a_{4} \Delta N I_{i t} Q_{i t}+a_{5} \Delta N I_{i t} L E V_{i t}+\mu_{i t}
$$

where $A R_{i t}$ is the average abnormal return rate of the i company on t year; $\Delta N I_{i t}$ is the change in the net income of $\mathrm{i}$ company on the $\mathrm{t}$ year; $T R A_{i t}$ is the dummy variable of the level of transparency of $\mathrm{i}$ company during the $t$ year, it takes the value of 1, if transparency level is high, the others are 0; SIZE is the natural logarithm of market value; $\mathrm{Q}$ is growth opportunity (market value divided by book value); LEV is debt ratio (total debt divided by total assets); $\mu_{i t}$ is the of error item. In this model, the earnings response coefficient of companies with lower levels of transparency is $a_{1}$; the earnings response coefficient of companies with higher levels of transparency is $a_{1}+a_{2}$. 


\section{Variable Measurement and Sample Selection}

\section{Measurement of Variables}

Following prior studies, a number of control variables are used in the regression model to control for potential influences on ERC (e.g. Fan and Wong 2002). The variables used include firm size, growth opportunity and debt ratio. The definitions of variables and their expected signs are summarized in Table 1.

Table 1: Definition of Variables

\begin{tabular}{|l|l|c|}
\hline \multicolumn{1}{|c|}{ Variables } & \multicolumn{1}{|c|}{ Definition } & Expected Sign \\
\hline AR & Abnormal Return = Actual return- market return. & + \\
$\Delta \mathrm{NI}$ & Change in net income divided by lagged total assets. & + \\
TRA & $\begin{array}{l}\text { Transparency level, taking the value of 1 if selected by SFI as the more } \\
\text { transparent companies and 0 otherwise; } \\
\text { Or taking the value of 1 if the ratio of long-term stock investment below the } \\
\end{array}$ & median of all sample firms and 0 otherwise. The ratio of long-term stock \\
& investment is defined as long-term stock investment divided by total assets. & + \\
SIZE & Company size = natural logarithm of market value & + \\
Q & Growth opportunity = market value divided by book value & - \\
LEV & Debt ratio = total debt divided by total assets & + \\
\hline
\end{tabular}

Lang and Lundholm (1993) find that firms with higher disclosure scores are larger than firms with lower scores. Collins and Kothari (1989) find that the returns of larger firms impound earnings news on a more timely basis than the returns of smaller firms. Size might be an important variable in determining ERC. The study of Vafeas(2000) pointed out that in the link between earnings and returns, the company's size is a major decisive factor.

The efficient market will be aware of the growth opportunities before they are recognized in net income and will bid up share price accordingly. Collins and Kothari (1989) find a positive relationship between growth opportunity and ERC. They use the ratio of market value of equity to book value of equity as a measure of growth opportunities. Smith and Watts (1992) also find that there is positive relationship between diluted securities and company growth. When a company issues diluted securities, there is a higher growth opportunity; then the earnings response coefficient is also higher. This is why, high company growth opportunity implies that there is an increase in the company's earnings-return ratio; investors will have a more significant reaction towards the current earnings. Consequently, earnings information will be reflected better on the company's stock prices.

Dhaliwal and Reynolds (1994) find that there is a negative relationship between earnings response coefficient and bond assessment and debt-equity ratio. In the study of Billing (1999), it shows that level of debt has a negative relationship on the earnings response coefficient; this also means that level of debt has a negative effect on the informativeness of earnings.

\section{Sample Selection}

The sample is drawn from all the TSEC and OTC listed companies in 2003 and 2004. The levels of information transparency come from the ranking results of ITDRS announced by the FSI. Relevant financial and return on stock data came from the Taiwan Economic Journal (TEJ) database.

Firms in financial and insurance industries are excluded from the sample because of their different firm characteristics. Firms with inadequate data are also deleted. The final sample consists of 841 firms in 2003 and 925 firms in 2004; a total of 1766 firm-years from 18 industries. 


\section{EMPIRICAL RESULTS AND ANALYSIS}

\section{Descriptive Statistics}

Table 2 is the summary of descriptive statistics of the 1766 observations. Among these, the average of the abnormal return rate (AR) is -0.0961 ; average change in net income $(\Delta \mathrm{NI})$ is 0.0151 . When transparency is measured by the ranking of ITDRS of the SFI, out of 1766 TESC-listed companies, 569 companies were selected as "the More Transparent Companies" (taking the value of 1); the other 1197 companies were considered not so transparent (taking the value of 0). With transparency level measured by ratio of long-term stock investment, 883 out of the 1766 companies were considered as the more transparent (taking the value of 1); the other 883 companies were considered less transparent (taking the value of 0 ).

Table 2: Summary Of Descriptive Statistics

\begin{tabular}{|cccccccc|}
\hline Variable & Year & N & Mean & Median & $\begin{array}{c}\text { Standard } \\
\text { Deviation }\end{array}$ & Minimum & Maximum \\
\hline AR & 2003 & 841 & -0.0041 & -0.1346 & 0.55154 & -0.96391 & 6.17698 \\
& 2004 & 925 & -0.0740 & -0.1111 & 0.39796 & -0.85443 & 2.19488 \\
$\Delta$ NI & $2003 \sim 4$ & 1766 & -0.0407 & -0.1219 & 0.47843 & -0.96391 & 6.17698 \\
& 2003 & 841 & 0.0196 & 0.0105 & 0.06953 & -0.24924 & 0.59868 \\
& 2004 & 925 & 0.0115 & 0.0096 & 0.07853 & -0.47784 & 0.49598 \\
$\Delta$ NI x TRA ${ }^{a}$ & $2003 \sim 4$ & 1766 & 0.0154 & 0.0100 & 0.07447 & -0.47784 & 0.59868 \\
& 2003 & 841 & 0.0062 & 0.0000 & 0.03574 & -0.24565 & 0.36534 \\
$\Delta$ NI x TRA ${ }^{b}$ & 2004 & 925 & 0.0048 & 0.0000 & 0.04970 & -0.47784 & 0.49598 \\
& $2003 \sim 4$ & 1766 & 0.0068 & 0.0000 & 0.05661 & -0.35754 & 0.59867 \\
$\Delta$ NI x SIZE & 2003 & 841 & 0.01052 & 0.00000 & 0.05572 & -0.24565 & 0.59867 \\
& 2004 & 925 & 0.00899 & 0.00000 & 0.05674 & -0.35754 & 0.26930 \\
$\Delta$ NI x Q & $2003 \sim 4$ & 1766 & 0.00972 & 0.00000 & 0.05624 & -0.35754 & 0.59867 \\
& 2004 & 841 & 0.1534 & 0.0801 & 0.51572 & -2.43521 & 3.60315 \\
& $2003 \sim 4$ & 1766 & 0.0999 & 0.0758 & 0.63432 & -3.69586 & 3.27423 \\
$\Delta$ NI*LEV & 2003 & 841 & 0.0287 & 0.0110 & 0.58132 & -3.69586 & 3.60315 \\
& 2004 & 925 & 0.0200 & 0.0108 & 0.13819 & -1.05434 & 0.99707 \\
& $2003 \sim 4$ & 1766 & 0.0241 & 0.0109 & 0.12774 & -1.05434 & 1.25838 \\
& 2003 & 841 & 0.0084 & 0.0040 & 0.03726 & -0.10111 & 0.53862 \\
& $2003 \sim 4$ & 925 & 0.0059 & 0.0032 & 0.03395 & -0.17161 & 0.25333 \\
& 1766 & 0.0071 & 0.0036 & 0.03557 & -0.17161 & 0.53862 \\
\hline
\end{tabular}

a: Information transparency, measured by the outcomes of IDES; 569 out of 1766 samples take the value of 1 (the more transparent); 1197 samples take the value of 0 (the less transparent).

b: Information transparency, measured by the ratio of long-term equity investment; 883 out of 1766 samples take the value of 1 (the ratio below the median, which is labeled as the more transparent); 883 samples take the value of 0 (the ratio above the median, which is labeled as the less transparent).

\section{Informativeness Of Accounting Earnings}

Before analyzing the effects of financial transparency on the informativeness of accounting earnings, first, one needs to understand whether accounting earnings can explain the average abnormal return on stocks. In the model of Table 3, $a_{1}$ coefficient shows the earnings response coefficient. The empirical results of Table 3 show that, earnings and average abnormal return have significant positive relationship. This means that the higher the reported earnings, the larger the average abnormal return on company stocks. 
Table 3: Regression Results Of Earnings On Abnormal Return

(Years 2003 and 2004)

\begin{tabular}{|c|c|}
\hline & $A R_{i t}=a_{0}+a_{1} \Delta N I_{i t}+\mu_{i t}$ \\
\hline Variables $^{\mathbf{a}}$ & Coefficient (t value) \\
\hline Intercept & $-0.0867^{* * * *}$ \\
& $(-8.4324)$ \\
$\Delta \mathrm{NI}$ & $2.9959^{* * * *}$ \\
& $(22.1400)$ \\
\hline F value & $490.1783^{* * *}$ \\
\hline Adj R-sq & 0.2175 \\
\hline No. of observations & 1766 \\
\hline
\end{tabular}

a. Definitions of variables are in Table 1.

$* * *$ Indicates significant at the $1 \%$ level; ** Indicates significant at the $5 \%$ level;

* Indicates significant at the $10 \%$ level.

\section{Effect Of Information Transparency On Informativeness Of Accounting Earnings}

In the model of Table 4, the ERC of companies with lower levels of transparency is $a_{1}$ and the ERC of companies with higher levels of transparency is $a_{1}+a_{2}$. The transparency level in column 1 of Table 4 is measured by the ITDRS ranking results; empirical results show that there is a negative association between transparency and the informativeness of accounting earnings (significant at 5\% level); in this instance, companies selected as the more transparent have lower earnings response coefficients. The result suggests that ITDRS has serious adverse selection problem. In terms of control variables, the positive coefficient of the company size ( $\Delta$ NI x SIZE) is consistent with the expected sign and has reached the significant level of $1 \%$; the growth opportunity ( $\Delta \mathrm{NI} \times \mathrm{Q})$ shows significant negative relationship which is not expected. Because high growth companies have higher risks, the growth opportunity ( $\triangle \mathrm{NI} \times \mathrm{Q}$ ) may be affected by the company's risks. Moreover, debt ratio ( $\triangle \mathrm{NI} \times \mathrm{LEV}$ ) shows significant negative relationship as expected.

The transparency level in column 2 of Table 4 is measured by the ratio of long-term investment in stocks; results show that information transparency is positively associated with the informativeness of accounting earnings (significant at $1 \%$ level). The result supports the hypothesis that companies with higher financial transparency have higher earnings response coefficients. The significance level and expected sign of control variables are all the same as column 1.

Overall, after controlling other factors that may affect ERC, the empirical results shows that transparency, measured by ITDRS cannot increase the informativeness of earnings. On the contrary, transparency level, measured by the ratio of long-term stock investment can further increase the informativeness of accounting earnings. From the disparity comparison of the two items, this study infers that the level of financial transparency is what investors look out for and the ITDRS is not a good proxy to use for measuring the level of corporate transparency. In terms of information disclosure, majority of the companies adhere to the rule of mandatory disclosure; what the ITDRS reflects is merely the discrepancy of the portion voluntarily disclosed. In addition, the indicators used are too complex; it may be impossible to use them appropriately in all industries or individual companies. This makes the empirical results less reliable than expected.

On another front, the ratio of long-term stock investment can better reflect the financial transparency of the company because the company can carry out earnings management through a mother company/subsidiary or cross stock holdings. It may even achieve the goal of manipulating financial reports, resulting in information asymmetry between managers and investors. If the investor is a bit incautious, or unable to see the lurking danger, the result may be incalculable loss. Consequently, in measuring corporate transparency, investors should focus on the company's ratio of long-term stock rights. We believe that companies with excessively high long-term stock rights ratio have lower financial transparency and lower ERC. 
Table 4: Regression Results Of Transparency And Control Variables On Abnormal Return (Years 2003 and 2004)

\begin{tabular}{|c|c|c|}
\hline \multicolumn{3}{|c|}{$A R_{i t}=a_{0}+a_{1} \Delta N I_{i t}+a_{2} \Delta N I_{i t} T R A_{i t}+a_{3} \Delta N I_{i t} S I Z E_{i t}+a_{4} \Delta N I_{i t} Q_{i t}+a_{5} \Delta N I_{i t} L E V_{i t}+\mu_{i t}$} \\
\hline & $\begin{array}{l}\text { Transparency measured by the ranking of } \\
\text { ITDRS }\end{array}$ & $\begin{array}{c}\text { Transparency measured by the ratio of } \\
\text { long-term equity investment }\end{array}$ \\
\hline Variables $^{\mathrm{a}}$ & $\begin{array}{c}\text { Coefficient } \\
\text { (t value) }\end{array}$ & $\begin{array}{c}\text { Coefficient } \\
\text { (t value) }\end{array}$ \\
\hline Intercept & $\begin{array}{c}-0.0864 * * * \\
(-8.4453)\end{array}$ & $\begin{array}{c}-0.0874 * * * \\
(-8.5622)\end{array}$ \\
\hline$\Delta \mathrm{NI}$ & $\begin{array}{c}3.4610 * * * \\
(3.9726)\end{array}$ & $\begin{array}{l}3.0880 * * * \\
(3.5256)\end{array}$ \\
\hline$\Delta \mathrm{NI} \times \mathrm{TRA}$ & $\begin{array}{l}-0.6916^{* *} \\
(-23494)\end{array}$ & $1.1033 * * *$ \\
\hline$\Delta \mathrm{NI} \times \mathrm{SIZE}$ & $\begin{array}{c}0.2806 * * * \\
(2.8346)\end{array}$ & $\begin{array}{c}0.2738 * * * \\
(2.8270)\end{array}$ \\
\hline$\Delta \mathrm{NI} \times \mathrm{Q}$ & $-0.8394 * * *$ & $-0.9827 * * *$ \\
\hline$\Delta \mathrm{NI} \times \mathrm{LEV}$ & $\begin{array}{l}-2.6173 * * * \\
(-3.6930)\end{array}$ & $\begin{array}{c}-3.1065 * * * \\
(-4.3034)\end{array}$ \\
\hline F value & $107.3469 * * *$ & $110.0676 * * *$ \\
\hline Adj R-sq & 0.2315 & 0.2360 \\
\hline No. of observations & 1766 & 1766 \\
\hline
\end{tabular}

a. Definitions of variables are in Table 1 .

*** Indicates significant at the $1 \%$ level; ** Indicates significant at the $5 \%$ level;

* Indicates significant at the $10 \%$ level.

\section{Checks Of Robustness}

About one third (569 out of 1766) of companies are selected as the more transparent companies by the SFI , but half of the sample companies are classified as the more transparent companies by the ratio of long-term stock investment. To avoid any possible measurement bias, we reselect only 569 companies as the more transparent companies using the criterion of ratio of long-term stock investment and rerun the regression model. The results are virtually the same as previous reported. We also rerun the regression year by year as a sensitivity test. The results are not much different from the pooling sample. The above diagnostic checks have demonstrated that our empirical results are robust to any possible bias.

\section{CONCLUSION}

The study uses listed companies in Taiwan from 2003 and 2004 as samples to study the relations between information transparency and informativeness of accounting earnings. Information transparency is measured by the ranking results of the ITDRS of the SFI and the ratio of long-term stock investment respectively.

Empirical results show that information transparency (as measured by the ratio of long-term stock investment) is positively associated with the informativeness of accounting earnings; this is why companies with higher financial transparency have higher earnings response coefficients. Adversely, when information transparency is measured by the ranking results of ITDRS, there is a negative association between transparency and the informativeness of accounting earnings; in this instance, companies selected as the more transparent have lower earnings response coefficients. We believe that although the indicators used by the ITDRS are comprehensive, using all the indicators as the common transparency level for all companies may result in the indicators to lose fidelity. Because of this, it may not be possible to highlight the level of transparency a company or business entity should have. On the other hand, in only using long-term stock investment ratio for corporate transparency has better result than that of ITDRS. It suggests that accounting numbers are more useful or valuable than the ITDRS ranking results from investors' perspective. It also suggests that the ITDRS may be not a good proxy for financial transparency. The implication is 
that the disclosure or regulation of long-term stock investment needs to be improved in order to increase the transparency of listed companies and to enhance the value of accounting numbers.

\section{REFERENCES}

1. Asian Wall Street Journal, 1999, Business transparency in region has worsened, survey shows, November 24, 5.

2. Barnea, A., Haugen, R. Q., and L.W. Senbet. 1985. Agency problems and financial contracting. Englewood Cliffs : Prentice-Hall.

3. Beaver, W., Clark W.H.R. and W.F. Wright. 1979. The association between unsystematic security returns and the magnitude of earnings forecast errors. Journal of Accounting Research 17(2): 316-340.

4. Bens, D.A. and S.J. Monahan. 2004. Disclosure quality and the excess value of diversification. Journal of Accounting Research 42(4): 691-711.

5. Billings, B.K. 1999. Revisiting the relation between the default risk of debt and the earnings response coefficient. The Accounting Review 74(4): 509-523.

6. Botosan, C.A. 1997. Disclosure level and the cost of equity capital. The Accounting Review 72(3): 323-349.

7. Brown, S. J., and J. B.Warner. 1980. Measuring security price performance. Journal of Financial Economics 8(3): 205-258.

8. Brown, S. J., and J. B.Warner. 1985. Using daily stock returns: the case of event study. Journal of Financial Economics 14(1): 3-32.

9. Chang, H.J. 1999. The relationship between long-term investment and share price. Accounting Research Monthly 162: 62-65. (in Chinese).

10. Chang, H.J. 2002. The relationship between long-term investment and share price: a consolidated statement perspective. Accounting Research Monthly 199: 115-121. (in Chinese).

11. Chang, R.D. and C.J. Fang. 2006. Effects of the information disclosure and evaluation system on earnings management. International Journal of Accounting Studies 42: 1-22. (in Chinese).

12. Chen, G.J., Y.C. Chen and H.J. Chen. 2005. An empirical study of influential determinants on information transparency of listed corporations at web sites. Journal of Accounting and Corporate Governance 2(1): 33-59. (in Chinese).

13. Collins, D.W., and S.P. Kothari and J. Rayburn. 1987. Firm size and the information content of prices with respect to earnings. Journal of Accounting and Economics 9: 111-138.

14. Collins, D.W., and S.P. Kothari. 1989. An analysis of intertemporal and cross-sectional determinants of earnings response coefficient. Journal of Accounting and Economics 11(2-3): 143-181.

15. Cooke, T.E. 1991. An assessment of voluntary disclosure in the annual reports of Japanese corporations. The International Journal of Accounting 26: 174-189.

16. Dhaliwal, D.S. and S.S. Reynolds. 1994. The effect of the default risk of debt on the earnings response coefficient. The Accounting Review 69(2): 412-419.

17. Diamond, D.W., and R.E. Verrecchia. 1991. Disclosure, liquidity, and the cost capital. The Journal of Finance 46(4): 1325-1360.

18. Elliott, R.K. and P.D. Jacobson. 1994. Cost and benefits of business information disclosure. Accounting Horizons 8(4): 80-96.

19. Fan, Joseph P.H., T.J. Wong. 2002. Corporate ownership structure and the informativeness of accounting earnings in East Asia. Journal of Accounting and Economics 33(3): 401-425.

20. Gelb, D.S., Paul Zarowin. 2002. Corporate disclosure policy and the informativeness of stock price. Review of Accounting Studies 7(1): 33-53.

21. Healy, P. M., A. P. Hutton, and K.G. Palepu. 1999. Stock performance and intermediation changes surrounding sustained increases in disclosure. Contemporary Accounting Research 16(3): 485-520.

22. Healy, P.M., K.G. Palepu. 2001. Information asymmetry, corporate disclosure, and the capital markets: A review of the empirical disclosure literature. Journal of Accounting and Economics 31(1-3): 405-440.

23. Ho, S.S.M., and K.S. Wong. 2001. A study of the relationship between corporate governance structures and the extent of voluntary disclosure. Journal of International Accounting, Auditing \& Taxation 10(2): 139-156.

24. Hsue, M.L. 2002. Information transparency and enterprise competitiveness. Accounting Research Monthly 200: 14-15. (in Chinese).

25. Lang, M.H and R.J. Lundholm. 1993. Cross-sectional determinants of analysts ratings of corporate disclosures. Journal of Accounting Research 31: 246-271. 
26. Lang, M.H and R.J. Lundholm. 2000. Voluntary disclosure and equity offerings: reducing information asymmetry or hyping the stock? Contemporary Accounting Research 17(4): 623-662.

27. Leftwich, R., R. Watts and J. Zimmerman. 1981. Voluntary corporate disclosure: the case of interim reporting. Journal of Accounting Research 19(supplement): 50-77.

28. Meek, Gary K., Clare B. Roberts, Sidney J. Gray. 1995. Factors influencing voluntary annual report disclosure by U.S., U.K. and continental European multinational corporations. Journal of International Business Studies 26(3): 555-572.

29. Smith, C.W. and R.L. Watts. 1992. The investment opportunity and corporate financing, dividend, and compensation policies. Journal of Financial Economics. 32(3): 263-293.

30. Strong, N. and M. Walker. 1993. The explanatory power of earnings and stock returns. The Accounting Review 68(2): 385-399.

31. Vafeas, N. 2000. Board structure and the informativeness of earnings. Journal of Accounting and Public Policy 19(2): 139-160.

32. Welker, M. 1995. Disclosure policy, information asymmetry, and liquidity in equity markets. Contemporary Accounting Research. 11(2): 801-828.

33. World Bank. 1998. East Asia: the road to recovery. World Bank. Washington DC.

34. Yeh, Y.H.2002. The information transparency of listed corporations at web sites. Accounting Research Monthly 200: 70-77. (in Chinese).

35. Yeh, Y.H.2004. The case of Procomp: the corporate governance of banks. Accounting Research Monthly 225: 50-53. (in Chinese).

\section{NOTES}

